\title{
Combination of lutetium-177 labelled anti- L1CAM antibody chCE7 with the clinically relevant protein kinase inhibitor MK1775: a novel combination against human ovarian carcinoma
}

Dennis Lindenblatt', Nastassja Terraneo', Giovanni Pellegrini², Susan Cohrs', Philipp René Spycher', David Vukovic ${ }^{1}$, Martin Béhé ${ }^{1}$, Roger Schibli ${ }^{1,3}$ and Jürgen Grünberg ${ }^{1 *}$

\begin{abstract}
Background: Protein kinase inhibitors (PKIs) are currently tested in clinical studies (phase I-III) as an alternative strategy against (recurrent) ovarian cancer. Besides their anti-tumour efficacy, several PKIs have also shown radiosensitizing effects when combined with external beam radiation. Based on these results we asked if the addition of PKls offers a therapeutic opportunity to improve radioimmunotherapy (RIT) against ovarian cancer. Five PKIs (alisertib, MK1775, MK2206, saracatinib, temsirolimus) were chosen for cytotoxicity screenings based on their current clinical trials in the treatment of ovarian cancer and their influence on cell cycle regulation and DNA damage repair pathways. We combined selected PKIs with ${ }^{177}$ Lu-labelled anti-L1CAM monoclonal antibody chCE7 for our investigations.
\end{abstract}

Methods: PKIs cytotoxicity was determined via cell colony-forming assays. Biomarker of DNA double-strand breaks (DSBs, $y$ H2A.X) was analysed by western blot and fluorescence microscopy. Flow cytometric measurements were performed to evaluate levels of apoptosis based on mono- or combination treatments. The best combination was used for in vivo combination therapy studies in nude mice with SKOV3ip and IGROV1 human ovarian cancer xenografts. Bonferroni correction was used to determine statistical significance for multiple comparisons.

Results: The highest cytotoxicity against both cell lines was observed for MK1775 and alisertib. Combinations including ${ }^{177}$ Lu-labelled mAb chCE7 and MK1775 decreased ${ }^{177}$ Lu-DOTA-chCE7 IC 60 -Values 14-fold, compared to 6-fold, when the radioimmunoconjugate was combined with alisertib. The most effective PKI MK1775 was further evaluated and demonstrated synergistic effects in combination with ${ }^{177}$ Lu-DOTA-chCE7 against IGROV1 cells. Significantly higher amounts of DSBs were detected in IGROV1 cells after combination (91\%) compared to either treatment alone (MK1775: 52\%; radioimmunoconjugate: 72\%; $p<0.0125)$. Early-apoptosis was significantly enhanced in IGROV1 cells correlating with induced DSBs ( ${ }^{177}$ Lu-DOTA-chCE7: 8\%, MK1775: 28\%, ${ }^{177}$ Lu-DOTA-ChCE7 + MK1775: 40\%, $\left.p<0.0125\right)$.

Immunohistochemistry analysis of $\mathrm{YH} 2 \mathrm{~A}$.X expression levels after therapy in SKOV3ip xenografts revealed a high sensitivity of the tumour cells to MK1775 and a high radioresistance. A prominent effect of tumour growth inhibition of the RIT and of the combination therapy was observed in vivo in a late stage IGROV1 xenograft model.

(Continued on next page)

\footnotetext{
* Correspondence: juergen.gruenberg@psi.ch

${ }^{1}$ Center for Radiopharmaceutical Sciences ETH-PSI-USZ, Paul Scherrer

Institute, 5232 Villigen PSI, Switzerland

Full list of author information is available at the end of the article
}

(c) The Author(s). 2018 Open Access This article is distributed under the terms of the Creative Commons Attribution 4.0 International License (http://creativecommons.org/licenses/by/4.0/), which permits unrestricted use, distribution, and reproduction in any medium, provided you give appropriate credit to the original author(s) and the source, provide a link to the Creative Commons license, and indicate if changes were made. The Creative Commons Public Domain Dedication waiver (http://creativecommons.org/publicdomain/zero/1.0/) applies to the data made available in this article, unless otherwise stated. 
(Continued from previous page)

Conclusions: Our results warrant further evaluation of combination of MK1775 and radioimmunotherapy.

Keywords: Protein kinase inhibitor, MK1775 (AZD1775), Ovarian carcinoma, L1CAM, mAb chCE7, ${ }^{177}{ }^{L u-}$ radioimmunotherapy, Combination therapy

\section{Background}

Today, epithelial ovarian cancer (OC) represents the most severe gynaecological cancer in women. Approximately $75 \%$ of the affected patients are being diagnosed with advanced-stage III or IV, since diagnostic markers and clinical symptoms during early stages are mostly absent [1]. Cytoreductive surgery and paclitaxel-platinum chemotherapy represent the most efficient therapy options for advanced OC. Despite good response rates towards chemotherapies (50-80\%), the major issue stays the rather high relapse rate in patients within 2 years including development of taxane or platinum resistant tumours [2, 3].

Modern chemotherapeutic agents like etoposide, gemcitabine, topotecan or pegylated liposomal doxorubicin are frequently used against recurrent ovarian cancers, but unfortunately, with very limited response rates between 15 and 30\% [4-7].

Given the high relapse rate of recurrent platinum-resistant OC, overall survival is still limited (approx. 40\%) [8]. Alternative screening and therapy strategies are urgently needed. New targeted therapies have been investigated during the last couple of years with the goal to increase overall survival and reduce side-effects. Therefore, various monoclonal antibodies (mAbs) have been studied as a targeted treatment alternative [9]. Unfortunately, mAb-based mono- or combination therapies showed only limited clinical efficacies against advanced OC despite promising pre-clinical results [10-13]. Many research groups focus on alternative therapeutic strategies including several protein kinase inhibitors (PKIs) targeting different signalling pathways or the DNA repair machinery of cancer cells. Besides their efficacy against (recurrent) OC, several PKIs also demonstrated radiosensitizing effects when combined with ionizing radiation (external beam radiation, EBRT) [14-16].

In previous studies we demonstrated the efficacy of anti-L1CAM radionuclide-labelled $\mathrm{mAb}$ chCE7 $\left({ }^{177} \mathrm{Lu},{ }^{161} \mathrm{~Tb},{ }^{67} \mathrm{Cu}\right)$ as monotreatment or when combined with the chemotherapeutic paclitaxel (PTX) against disseminated OC [17-20]. Based on these findings we explored a new approach investigating the potential synergy between PKIs and anti-L1CAM radioimmunotherapy (RIT) against OC. In this context is worth mentioning that high expression of L1CAM in OC is associated with the rapid growth of aggressive tumours and a poor prognosis for the patients [21]. L1CAM "is a major driver for tumour cell invasion and motility" [22].

Five PKIs were chosen for initial cytotoxicity screenings based on their current clinical studies (OC clinical trials I-II) and their potential radiosensitizing characteristics. Briefly, PKIs candidates were chosen as follows:

Alisertib, an Aurora kinase A PKI, showed modest results in a clinical phase II trial against platinum-resistant or refractory OC [23]. Additionally, a phase I trial is ongoing for the therapy of recurrent $\mathrm{OC}$ in combination with the chemotherapeutic PTX (clinical trial identifier: NCT01091428). Alisertib has shown to sensitize glioblastoma cells against radiation in vitro [14].

MK1775 also known as AZD1775 is an ATP-competitive inhibitor of Wee1 tyrosine kinase. Wee1 is one of two kinases (Wee1 and Mik1) that catalyse inhibitory phosphorylation on the CDC2-cyclin B complex [24, 25]. Inhibition of Wee1 abrogates the G2/M arrest and leads to compelled progression to mitosis despite damaged DNA resulting in mitotic catastrophe [26]. MK1775 is under investigation in different clinical trials (Phase II) in combination with gemcitabine, carboplatin or paclitaxel against OC (clinical trial identifier: NCT02101775 and NCT02272790) and has previously shown radiosensitizing characteristics in vivo when combined with ionizing radiation for the treatment of intrinsic potine gliomas [27].

Temsirolismus is a mTOR inhibitor which has shown modest, but not sufficient anti-tumour activity in a recent phase II clinical trial as a monotherapy against persistent/recurrent OC $[28,29]$. A clinical phase II study where temsirolimus was combined with bevacizumab has been completed but no study results have been published yet (clinical trial identifier: NCT01010126). The radiosensitizing abilities of temsirolismus were shown in vivo in a glioblastoma model [30].

Saracatinib is an inhibitor of Src tyrosine kinase and was investigated in a phase II trial assessing its use in combination with PTX and carboplatin in advanced OC (clinical trial identifier: NCT00610714). However, results remain to be published. Saracatinib revealed sensitizing effects towards ionizing radiation in a lung cancer in vitro model [16].

MK2206 is a highly selective inhibitor of Akt kinase and was tested in a phase II clinical trial against platinum-resistant $\mathrm{OC}$ (clinical trial identifier: NCT01283035) [31]. The study has been recently completed. In addition it was demonstrated in vitro, that 
MK2206 can sensitize triple negative breast cancer cells towards EBRT [32].

After initial in vitro screenings, we further investigated combinations including PKI MK1775 and the ${ }^{177} \mathrm{Lu}-\mathrm{la}$ belled mAb chCE7 in vivo. Two OC cell lines (IGROV1, p53wt, SKOV3ip, p53del) were used in our studies.

\section{Methods}

\section{Cell lines, culture conditions and antibody formats}

L1CAM positive SKOV3ip cells were kindly provided by P. Altevogt (German Cancer Research Center, Heidelberg, Germany). Cells were established from ascitic fluid of a nu/nu mouse that was previously injected with SKOV3 cells [33]. SKOV3ip cells were maintained in DMEM medium at $37{ }^{\circ} \mathrm{C}$. IGROV1 cells were a kind gift by Dr. Cristina Müller (Center for Radiopharmaceutical Sciences, Paul Scherrer Institute) and were maintained in RPMI 1640 medium at $37{ }^{\circ} \mathrm{C}$. Both cell media were supplemented with $10 \%$ fetal calf serum (FCS), $2 \mathrm{mM}$ glutamine, $100 \mathrm{units} / \mathrm{ml}$ penicillin, $100 \mu \mathrm{g} / \mathrm{ml}$ streptomycin and $0.25 \mu \mathrm{g} / \mathrm{ml}$ fungizone (BioConcept, Allschwil, Switzerland). The two cell lines were cultivated in a humidified atmosphere containing $5 \% \mathrm{CO}_{2}$. Cell lines were authenticated by STR profiling (Department of Molecular Medicine, Aarhus University Hospital, Denmark; DSMZ Authentication Service, Braunschweig, Germany) and were mycoplasma free (Mycoplasma test kit, AppliChem GmbH, Darmstadt, Germany). L1CAM expression in both cell lines was confirmed by flow cytometry (Additional file 1: Figure S1). The cell lines did not require ethics approval.

Chimeric monoclonal antibody mAb chCE7 (human $\mathrm{k}$ light chain and human $\gamma 1$ heavy chain) is an IgG1-subtype. MAb chCE7 was produced in HEK293 cells and subsequently purified from cell culture supernatant as previously described by Grünberg et al. [34].

\section{Ligand substitution and ${ }^{177} \mathrm{Lu}$ antibody radiolabelling} For ligand substitution, molar excess of p-SCN-Bn-DOTA (Macrocyclics, Dallas, TX, USA) was individually adopted to vary DOTA-to-mAb ratios for in vitro and in vivo experiments, respectively as described elsewhere [20]. Briefly, p-SCN-Bn-DOTA was mixed with mAb chCE7 in $0.1 \mathrm{~mol} / \mathrm{L}$ sodium phosphate buffer $(\mathrm{pH}$ 7.2). The $\mathrm{pH}$ was adjusted to $\mathrm{pH} 9-10$ using a saturated $\mathrm{Na}_{3} \mathrm{PO}_{4}$ solution and was incubated over night at $30{ }^{\circ} \mathrm{C}$ with gentle shaking. Using a NAP-5 column (GE Healthcare, Glattbrugg, Switzerland) excess ligands were removed and buffer was exchanged into $0.25 \mathrm{M} \mathrm{CH}_{3} \mathrm{COONH}_{4}$ (pH 5.5). Immunoconjugates were concentrated to $5 \mathrm{mg} / \mathrm{ml}$ and stored at $80{ }^{\circ} \mathrm{C}$. The number of chelators coupled to the mAb was determined by mass spectroscopy [17]. For radiolabelling, the radionuclide ${ }^{177} \mathrm{Lu}$ (ITG, Garching, Germany) was used 1 to 3 days post-specified calibration date. In brief,
$100-450 \mathrm{MBq}$ of ${ }^{177} \mathrm{Lu}$ was added to $150 \mu \mathrm{g}$ immunoconjugate and incubated in $0.25 \mathrm{M} \mathrm{CH}_{3} \mathrm{COONH}_{4}$ buffer (pH 5.5) at $37^{\circ} \mathrm{C}$ for $1 \mathrm{~h}$. After radiolabelling, EDTA was added to the reaction mixture (5 $\mathrm{min}$ ) to a final concentration of $5 \mathrm{mM}$ to complex free ${ }^{177} \mathrm{Lu}$. Radiolabelled antibodies were purified via FPLC size exclusion chromatography on a Superose 12 column (GE Healthcare, Glattbrugg, Switzerland) using phosphate-buffered saline (PBS) as eluent with a flow rate of $0.5 \mathrm{ml} / \mathrm{min}$. Radioimmunoconjugates (RICs) eluted with a retention time of $21 \mathrm{~min}$ [19]. The immunoreactive fraction [35] of labelled antibody conjugates ranged from 60 to $83 \%$.

\section{In vitro cytotoxicity assays}

In order to investigate the sensitivity of SKOV3ip and IGROV1 cells towards selected PKIs (alisertib, MK1775, MK2206, saracatinib, temsirolimus; all from Selleckchem, LuBioScience, Luzern, Switzerland) were solved in DMSO and the accordant half-maximal inhibitory concentration $\left(\mathrm{IC}_{50}\right)$ was determined via adapted colony-forming assays [36]. OC cells were seeded into 6-well plates with a density of 250 cells/well and incubated over night at $37{ }^{\circ} \mathrm{C}$. After adhesion cells were washed with PBS and incubated with the relevant PKI with concentrations ranging from 0.1 to $1000 \mathrm{nM}$ for $48 \mathrm{~h}$ at $37^{\circ} \mathrm{C}$. Cells were washed with PBS and covered with regular supplemented cell culture medium as previously described. Eleven to fourteen days post plating, colonies were washed with PBS, fixed and stained with crystal violet staining solution containing $0.05 \%$ crystal violet, $1 \%$ formaldehyde and $1 \% \mathrm{MeOH}$ for $15 \mathrm{~min}$ at room temperature (RT). Colonies were washed twice with PBS and manually counted ([36], adapted). Colonies containing more than 100 cells were considered for counting.

In combination experiments, cells were incubated with the half of the half-maximal inhibitory concentration (half $\mathrm{IC}_{50}$ ) of PKIs for $48 \mathrm{~h}$ at $37{ }^{\circ} \mathrm{C} .1 \mathrm{ml}{ }^{177} \mathrm{Lu}$-DOTA-chCE7 solution was added either before, simultaneously, or post PKI application in concentrations ranging from 0.05 to $5 \mathrm{MBq} / \mathrm{ml}$ for $8 \mathrm{~h}$ at $37^{\circ} \mathrm{C}$. The incubation medium was removed at the indicated time points and cells were washed with PBS and incubated with regular supplemented cell culture medium. Again, 11-14 days post plating, colonies were washed with PBS, fixed, stained and counted as described.

\section{Western blot analysis}

Cells were exposed to accordant mono- or combination treatments including $\mathrm{IC}_{50}$ of MK1775 $(300 \mathrm{nM})$ for $48 \mathrm{~h}$ and/or $5 \mathrm{MBq} / \mathrm{ml}^{177} \mathrm{Lu}$-DOTA-chCE7 $(5 \mathrm{ml})$ for $8 \mathrm{~h}$. Cell lysates were subject to SDS-polyacrylamide gelelectrophoresis. Proteins were transferred onto polyvinylidene difluoride (PVDF) membranes (Immobilon, Merck, Schaffhausen, Switzerland) via a semi-dry 
blotting device (Bio-Rad Laboratories AG, Reinach, Switzerland) and incubated with primary anti-CDC2 $(1 / 1000)$-pCDC2 (Tyr-15; 1/1000) or -GADPH (1/ 1000) antibodies (Cell Signaling Technology, Bioconcept, Allschwill, Switzerland). Detection of proteins was performed with secondary anti-mouse IgG HRP-linked antibody (1/2000, 30 min, RT; Cell Signaling Technology, Bioconcept, Allschwill, Switzerland) and ECL chemiluminescence kit (Perbio Science Switzerland S.A., Lausanne, Switzerland). All antibody dilutions were made in TBST $/ 2 \%$ BSA and were incubated over night at $4{ }^{\circ} \mathrm{C}$.

For the detection of histone phosphorylation $\gamma \mathrm{H} 2 \mathrm{~A} . \mathrm{X}$ (Ser-139) Abcam's histone extraction protocol was used. Briefly, cells were detached from plates and washed twice with ice-cold PBS containing $5 \mathrm{nM}$ sodium butyrate to retain levels of histone acetylation. Washed cells were resuspended and incubated for $10 \mathrm{~min}$ in triton extraction buffer (TEB) containing 0.5\% triton-X $100(\mathrm{v} / \mathrm{v})$, $2 \mathrm{mM}$ phenylmethylsulfonylfluoride (PMSF) and $0.02 \%$ $(w / v) \quad \mathrm{NaN}_{3}$. Suspended cells were centrifuged at $2000 \mathrm{rpm}$ for $10 \mathrm{~min}$ at $4{ }^{\circ} \mathrm{C}$, washed in half the volume of TEB buffer, centrifuged again $\left(2000 \mathrm{rpm} / 10 \mathrm{~min} / 4{ }^{\circ} \mathrm{C}\right)$ and incubated overnight $\left(4{ }^{\circ} \mathrm{C}\right)$ in $0.2 \mathrm{~N} \mathrm{HCl}(75 \mu \mathrm{L})$ to extract histones. The next day, cells were again centrifuged as before and the protein concentration of the supernatant determined via advanced protein assay reagent (Cytoskeleton, Inc., Denver, USA). Aliquots were stored at $-20{ }^{\circ} \mathrm{C}$ and subjected to western blot analysis as previously described.

\section{Fluorescence microscopy}

Cells were seeded in an 8-well chamber system (Nunc Lab-Tek II Chamberslides, Thermo Fisher Scientific, Reinach, Switzerland) with 15.000 cells per chamber and incubated over night at $37{ }^{\circ} \mathrm{C}$. After adhesion cells were treated with MK1775 $(100 \mathrm{nM}, 300 \mu \mathrm{l})$ for $48 \mathrm{~h}$ and/or $2.5 \mathrm{MBq} / \mathrm{ml}{ }^{177} \mathrm{Lu}$-DOTA-chCE7 (300 $\left.\mu \mathrm{l}\right)$ for $4 \mathrm{~h}$. Cells were washed three times with PBS and incubated for 15 min with $\mathrm{PBS} / 4 \%$ formaldehyde for fixation. Subsequently, cells were washed and incubated with $0.2 \%$ permeabilization buffer containing $0.03 \mathrm{M} \mathrm{NaCl}, 0.3 \mathrm{mM}$ $\mathrm{KH}_{2} \mathrm{PO}_{4}, 0.5 \mathrm{mM} \mathrm{Na}_{2} \mathrm{HPO}_{4}$ and 3\% triton-X 100 diluted with PBS for 15 min at RT. Cells were blocked with PBS/ $1 \%$ BSA, $0.3 \%$ Tween-20 for $45 \mathrm{~min}$ and incubated over night with the primary anti- $\gamma \mathrm{H} 2 \mathrm{~A} . \mathrm{X}$ antibody $\left(1 / 400,4{ }^{\circ} \mathrm{C}\right.$, Cell Signaling Technology, Bioconcept, Allschwill, Switzerland) diluted in blocking buffer. Cells were incubated with a reaction mixture containing secondary fluorescein isothiocyanate (FITC)-conjugated antibody (1/300, Abcam, Cambridge, UK) and phalloidin (1/200, Cell Signaling Technology, Bioconcept, Allschwill, Switzerland) for $30 \mathrm{~min}$ at RT, washed three times and stored at $4{ }^{\circ} \mathrm{C}$ in the dark. Samples were imaged with a Leica SP5 confocal microscope (Leica Microsystems, Switzerland) using a $50 \times 0.5 \mathrm{NA}$ dry objective. Fields were chosen at random locations. $\gamma \mathrm{H} 2 \mathrm{~A}$.X foci were calculated as a percentage of the total cells counted in each field.

\section{Apoptosis analysis via flow cytometry}

Cells were treated with $300 \mathrm{nM}$ MK1775 for $48 \mathrm{~h}$ and/or $5 \mathrm{MBq} / \mathrm{ml}{ }^{177} \mathrm{Lu}$-DOTA-chCE7 $(5 \mathrm{ml})$ for $8 \mathrm{~h}$, detached, washed and subjected to apoptosis analysis via flow cytometry using an annexinV-FITC/propidium iodide (PI) double staining. Cells were incubated for $15 \mathrm{~min}$ with an annexinV-FITC/PI reaction mixture containing $10 \mathrm{mM}$ Hepes/NaOH, pH 7.4; $140 \mathrm{mM} \mathrm{NaCl} ; 5 \mathrm{mM} \mathrm{CaCl}_{2}$; as well as $20 \mu \mathrm{l}$ of annexinV-FITC labelling reagent (Roche Diagnostics GmbH, Mannheim, Germany) and $20 \mu \mathrm{l}$ PI solution (Flucka, Buchs, Switzerland). Labelled cells were transferred into a 96-well plate, analysed by flow cytometry and results were evaluated with FlowJo software (Tree Star, Ashland, OR, USA, version 10).

\section{In vivo studies}

All animal experiments were approved by the cantonal committee on animal experiments and permitted by the responsible cantonal authorities (permission number 75666, Kanton Aargau). The studies were conducted in compliance with the Swiss laws on animal protection. For tumour growth, groups of 4-6 female CD-1 ${ }^{\text {nu }}$ mice (Charles River, Sulzfeld, Germany, 5 weeks old, with an average weight of $22 \mathrm{~g}$ ) were injected subcutaneously (s.c.) with $5 \times 10^{6}$ IGROV1 cells $(100 \mu \mathrm{l}$, in sterile PBS) into the right flank. One week before the radioimmunotherapy started, $200 \mu \mathrm{g}$ of murine IgG2a (\#M7769, Sigma-Aldrich, Buchs, Switzerland) was injected i.p. to minimize unspecific binding to murine Fcy and FcRn receptors. Nineteen days post tumour cell inoculation (mean tumour volume: $362 \pm 150 \mathrm{~mm}^{3}$, mean body weight: $24.8 \pm 1.6 \mathrm{~g}$ ) mice were treated with a) $6 \mathrm{MBq}$ (50\% maximum tolerated activity (MTA) [20], $25 \mu \mathrm{g}$, $100 \mu \mathrm{l}{ }^{177} \mathrm{Lu}$-DOTA-chCE7, b) $6 \mathrm{MBq}^{177} \mathrm{Lu}$-DOTA-isotype control antibody $(25 \mu \mathrm{g}, 100 \mu \mathrm{l})$ or c) PBS into the tail vein. In some treatment groups MK1775 $(50 \mathrm{mg} / \mathrm{kg}$, CliniSciences, Nanterre, France) was given in DMSO in 0.5\% methylcellulose (M0512; Sigma-Aldrich, Buchs, Switzerland) in a 1:14 suspension [37] by oral gavage on three consecutive days starting $48 \mathrm{~h}$ after RIT. The gavage needle was precoated with sucrose to reduce stress for the mice [38].

For the in vivo assessment of DNA damage, female CD- $1^{\text {nu }}$ mice ( $n=3$; Charles River, Sulzfeld, Germany) were subcutaneously (s.c.) injected with $5 \times 10^{6}$ SKOV3ip cells and 14 days later treated with $2 \mathrm{MBq}$ of intravenously (i.v.) administered ${ }^{177} \mathrm{Lu}$-DOTA-chCE7 alone or in combination with $50 \mathrm{mg} / \mathrm{kg}$ MK1775 administered p.o. $48 \mathrm{~h}$ after RICs. PKI doses were administered daily 
for 3 consecutive days. Accordantly, controls received PBS. Six days post therapy start all animals were euthanized. Subcutaneous xenografts were measured, removed and fixed in 4\% neutral-buffered formalin (Formafix, Hittnau, Switzerland) for $48 \mathrm{~h}$. After fixation tissues were trimmed, dehydrated in graded alcohol and routinely paraffin wax embedded. Consecutive sections (3-5 $\mu$ m thick) were prepared, mounted on glass slides and routinely stained with haematoxylin and eosin (HE) or subjected to immunohistochemical staining.

A rabbit polyclonal antibody against mouse phosphorylated $\gamma \mathrm{H} 2 \mathrm{~A}$.X histone antigen (antibody \#2577, Cell Signaling Technology, Bioconcept, Allschwill, Switzerland) was used to detect endogenous levels of $\gamma \mathrm{H} 2 \mathrm{~A} . \mathrm{X}$ when phosphorylated at serine 139 . Briefly, sections were deparaffinised in xylene rehydrated in decreasing concentrations of ethanol and subjected to antigen retrieval using $10 \mathrm{mM}$ Tris-EDTA buffer (pH 9.0) for $15 \mathrm{~min}$ at $98^{\circ} \mathrm{C}$. This was followed by incubation for $15-18 \mathrm{~h}$ at $4{ }^{\circ} \mathrm{C}$ with the primary antisera (1/50 dilution in Dako antibody diluent, Dako-Agilent Technologies, Denmark). A detection kit containing the secondary antibody and diaminobenzidinetetrahydrochloride (DAB) as chromogen was subsequently applied according to the manufacturer's protocols (Peroxidase/DAB+ Rabbit/Mouse Kit; DAKO-Agilent Technologies, Denmark), followed by light counterstain with hematoxylin.

An attempt was made to quantify the number of $\gamma \mathrm{H} 2 \mathrm{~A}$.X positive tumour cells. Slides were scanned using digital slide scanner NanoZoomer-XR C12000 (Hamamatsu, Japan) and images (10 images per sample, $40 \times$ ) were taken using NDP.view2 viewing software (Hamamatsu). Fields were selected just beneath the capsule of the xenografts, avoiding areas exhibiting liquefactive necrosis. Immuno-stained cells for $\gamma \mathrm{H} 2 \mathrm{~A}$.X were calculated as a percentage of the total cells counted in each field.

\section{Statistical analysis}

Statistical analysis of apoptosis, fluorescence microscopy, and histological data was performed using student's t-test (two-tailed, unpaired) with Bonferroni-correction. Significance was determined with $p<0.0125$. In vitro data was analysed via combination index calculations $\left(\mathrm{CI}=\left(C_{\mathrm{A}, x}\right)\right.$ $\left.\left.\mathrm{Ic}_{x, \mathrm{~A}}\right)+\left(C_{\mathrm{B}, x} / \mathrm{Ic}_{x, \mathrm{~B}}\right)\right)$. Thereby, concentrations required to produce a given effect are determined for drug $\mathrm{A}\left(\mathrm{Ic}_{x, \mathrm{~A}}\right)$ and drug $\mathrm{B}\left(\mathrm{Ic}_{x, \mathrm{~B}}\right) . C_{\mathrm{A}, x}$ and $C_{\mathrm{B}, x}$ are the concentrations of $\mathrm{A}$ and $\mathrm{B}$ contained in combination that provide the same effect. Synergy is determined for $\mathrm{CI}<1$, additivity for $\mathrm{CI}=1$ and antagonism for CI $>1$ [39].

\section{Results}

Antibody radiolabelling and ligand substitution

In order to determine the DOTA-to-mAb (chCE7) ratio a mass spectroscopic analysis was performed. Results showed that an average of 7.6 chelators was coupled to one intact antibody molecule for RICs used in in vitro experiments. For RICs utilized in the in vivo study an average of 2.7-3.1 chelators was coupled. Specific activity ranged from 2000 to $2850 \mathrm{MBq} / \mathrm{mg}$ for RICs with 7.6 chelators and $240-560 \mathrm{MBq} / \mathrm{mg}$ for RICs with $2.7-3.1$ chelators. Lindmo method [35] was used to prove the immunoreactive fraction of the radiolabelled mAbs (60$83 \%)$.

\section{Cytotoxicity of selected PKIs towards IGROV1 and SKOV3ip cells}

First we investigated the sensitivity of the IGROV1 and SKOV3ip OC cell lines towards the selected PKIs. Respective dose-response curves are shown in Fig. 1a-e and resulting $\mathrm{IC}_{50}$-values are summarised in Table 1 . PKIs alisertib and MK1775 showed $\mathrm{IC}_{50}$-values in the medium nanomolar range for both $\mathrm{OC}$ cell lines. Comparable sensitivities of SKOV3ip cells were observed towards the PKIs temsirolimus and MK2206. In comparison, $\mathrm{IC}_{50}$-values for temsirolimus and MK2206 against IGROV1 cells could only be estimated within in the micromolar range, since highest applied PKI concentration of $1 \mu \mathrm{M}$ was not sufficient enough to reach $\mathrm{IC}_{50}$. No cytotoxicity was detected for both cell lines based on the treatment with PKI saracatinib (Fig. 1b).

\section{MK1775 sensitizes IGROV1 cells towards treatment with ${ }^{177}$ Lu-DOTA ChCE7 in vitro}

PKIs saracatinib, MK2206 and temsirolimus showed only limited cytotoxicities against both $\mathrm{OC}$ cell lines and were therefore not considered for further investigations. First in vitro combination experiments were performed using the PKIs alisertib and MK1775 combined with ${ }^{177}$ Lu-DOTA-chCE7. Both PKIs demonstrated their ability to radiosensitize IGROV1 cells by lowering the inhibitory concentration of ${ }^{177} \mathrm{Lu}$-labelled $\mathrm{mAb}$ chCE7 necessary to reduce colony-forming ability to $60 \%$ of an untreated control $\left(\mathrm{IC}_{60}\right)$. However, MK1775 decreased the $\mathrm{IC}_{60}$-value of ${ }^{177} \mathrm{Lu}$-DOTA-chCE7 15 -fold compared to a 6-fold decrease observed for combinations including PKI alisertib (Additional file 1: Figure S2). In this experiment the cells were incubated for only $4 \mathrm{~h}$ instead of $8 \mathrm{~h}$ with ${ }^{177} \mathrm{Lu}$-labelled chCE7. The colony-forming ability was reduced by a maximum of $60 \%$ in comparison to the untreated cells even with the highest amount of radioactivity.

Based on these findings MK1775 demonstrated the most promising radiosensitizing effect and was therefore further investigated. Following experiments included the examination of different treatment sequences for combined applications of MK1775 and ${ }^{177} \mathrm{Lu}$-DOTA-chCE7 in IGROV1 cells. 

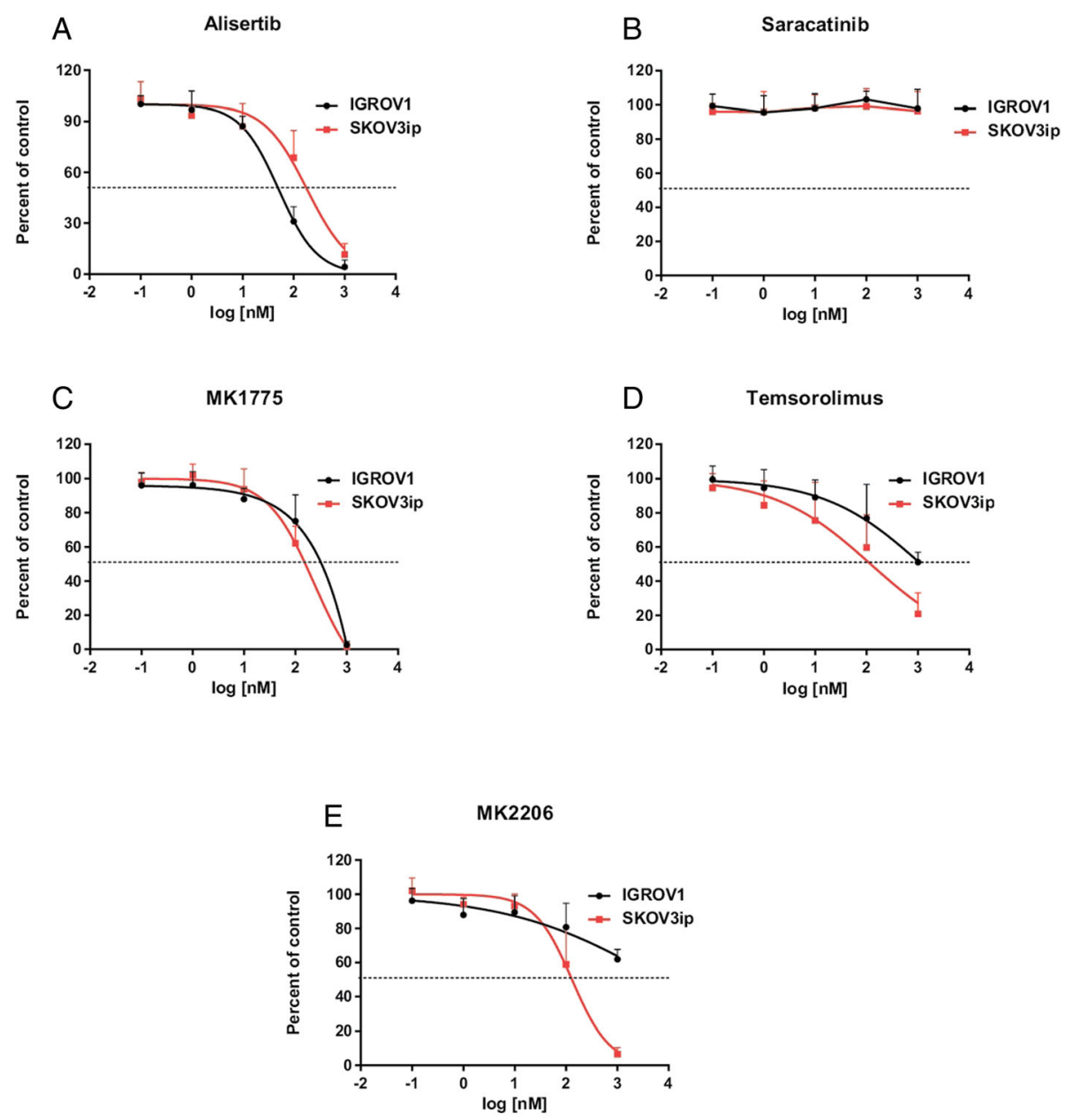

Fig. $1 \mid C_{50}$-values for a Alisertib, b Saracatinib, c MK1775, d Temsirolimus and e MK2206. IC $C_{50}$-values were determined by colony-forming assays. IGROV1 and SKOV3ip cells were incubated for $48 \mathrm{~h}$ with accordant PKI concentrations ranging from 0.1-1000 nM

The most prominent effects in IGROV1 were achieved when MK1775 (half $\mathrm{IC}_{50}$ ) was added simultaneously or post the radioimmunoconjugate (Fig. 2). $\mathrm{IC}_{50}$-value of ${ }^{177} \mathrm{Lu}$-DOTA-chCE7 was thereby lowered from 1.4 MBq/ $\mathrm{ml}$ to $0.8 \mathrm{MBq} / \mathrm{ml}$ (simultaneous application), or down to $0.5 \mathrm{MBq} / \mathrm{ml}$ (MK1775 post RIC). MK1775 pre-treated cells showed no increased sensitivity towards the RIC but rather an increased $\mathrm{IC}_{50}$-value of $3.9 \mathrm{MBq} / \mathrm{ml}$ compared to ${ }^{177} \mathrm{Lu}$-DOTA-chCE7 alone. Combination index (CI) calculations as previously described by Zhao et al. [39] were used to determine synergy (Fig. 2, calculations are shown in Additional file 1: Table S1). The additional application of MK1775 (half $\mathrm{IC}_{50}$ ) post ${ }^{177} \mathrm{Lu}-\mathrm{DO}$ TA-chCE7 increased the cytotoxic effect of the RIC in a synergistic manner $(\mathrm{CI}<1)$. The $\mathrm{IC}_{50}$ value for radioresistance towards ${ }^{177} \mathrm{Lu}$-DOTA-chCE7 was $4.7 \mathrm{MBq} / \mathrm{ml}$ for SKOV3ip cells (data not shown).

\section{The combination of MK1775 and RIC increases the} amount of induced DNA-double strand breaks (DSBs) compared to monotreatments in IGROV1 cells

In order to elucidate the molecular mechanism behind the observed radiosensitizing effect of the Wee1 kinase inhibitor MK1775 on IGROV1 cells we investigated the

Table 1 IC $5_{50}$-values for PKIs against IGROV1 and SKOV3ip cells

\begin{tabular}{llllll}
\hline & Alisertib & Saracatinib & MK1775 & Temsirolimus & MK2206 \\
\hline IGROV1 & $50 \pm 3 \mathrm{nM}$ & n.a. & $306 \pm 4 \mathrm{nM}$ & n.a. & n.a. \\
SKOV3ip & $158 \pm 3 \mathrm{nM}$ & n.a. & $133 \pm 4 \mathrm{nM}$ & $120 \pm 4 \mathrm{nM}$ & $131 \pm 3 \mathrm{nM}$ \\
\hline
\end{tabular}




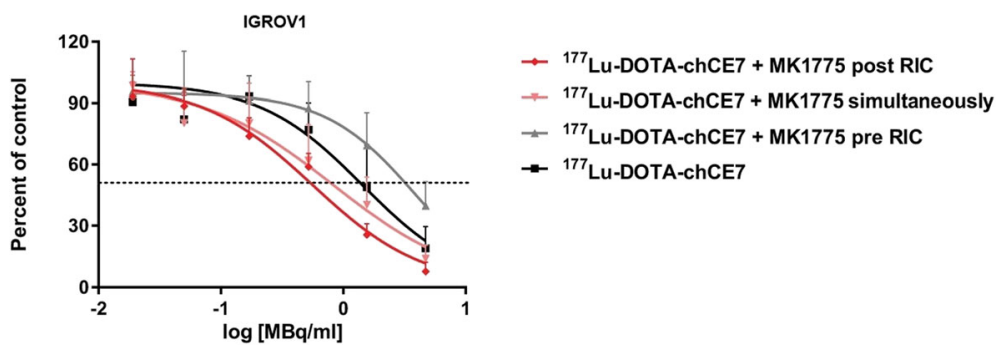

Fig. 2 Radiosensitivity of IGROV1 cells. The radiosensitivity was determined by colony-forming assays after combined treatments with ${ }^{177}$ LuDOTA-chCE7 (range: from 0.01-5.0 MBq/ml, for $8 \mathrm{~h}$ ) and MK1775 (applied simultaneously, $48 \mathrm{~h}$ post, or $48 \mathrm{~h}$ pre RIC with a concentration of half $\left.I C_{50}\right)$

phosphorylation status of cyclin-dependent-kinase 1 (alias CDC2), which is phosphorylated by protein kinase (PK) Wee1. Additionally, we correlated the phosphorylation of $\mathrm{CDC} 2$ (pCDC2) with the amount of induced DNA-DSBs by western blot analysis.

It seems, that in IGROV1 cells expression levels of CDC2 were similar independent of a RIC and/or MK1775 application. Phosphorylation status of CDC2 (pCDC2) looks equal for the control and ${ }^{177}$ Lu-DOTA-chCE7. However, mono- or combined treatments containing MK1775 appears to reduce the levels of pCDC2 compared to controls or ${ }^{177} \mathrm{Lu}$-DOTA-chCE7 (Fig. 3).

Phosphorylation of histone H2A.X at Ser-139 ( $\gamma$ H2A.X) was detected as an indicator for presence of DNA-DSBs. ${ }^{177}$ Lu-DOTA-chCE7 treated cells showed slightly higher amounts of $\gamma \mathrm{H} 2 \mathrm{~A} . \mathrm{X}$ compared to the control. The addition of MK1775 increased markedly the levels of $\gamma$ H2A.X compared to ${ }^{177} \mathrm{Lu}-\mathrm{DOTA}-\mathrm{chCE} 7$ and the untreated cells. Combination of the RIC and PKI MK1775 showed the highest levels of $\gamma \mathrm{H} 2 \mathrm{~A} . \mathrm{X}$, thus indicating the largest amount of induced DNA-DSBs compared to either treatment alone or the control (Fig. 3).

Fluorescence microscopy studies were conducted to quantify $\gamma \mathrm{H} 2 \mathrm{~A}$.X levels. The number of induced $\gamma \mathrm{H} 2 \mathrm{~A}$.X foci were counted and cells grouped depending on either no observed $\gamma \mathrm{H} 2 \mathrm{~A} . \mathrm{X}$ foci (Fig. 4a), count of foci per cell $\leq 5$ (Fig. 4b), count of foci per cell $\geq 6$ (Fig. 4c), or non-distinguishable $\gamma \mathrm{H} 2 \mathrm{~A} . \mathrm{X}$ foci (intensively positive, Fig. 4d). All counts are summarized in Additional file 1: Table S2. Figure 4e shows all $\gamma \mathrm{H} 2 \mathrm{~A}$.X positive cells expressed in percent of total cell numbers counted.

Non-treated IGROV1 cells were positively tested for $\gamma \mathrm{H} 2 \mathrm{~A}$.X foci $(52 \pm 19 \%)$, indicating that about half of IGROV1 cells show a basal level of existing of DNA-DSBs. After treatment with a low concentration of MK1775 (100 nM) IGROV1 showed comparable amounts of $\gamma \mathrm{H} 2 \mathrm{~A} . \mathrm{X}$ foci $(55 \pm 2 \%)$. In contrast, ${ }^{177} \mathrm{Lu}-\mathrm{DO}-$ TA-chCE7 application resulted in an increased number of $72 \pm 1 \%$. Highest amounts of induced DNA-DSBs were observed for the combination demonstrating $91 \pm 4 \%$ of IGROV1 cells being positive for $\gamma \mathrm{H} 2 \mathrm{~A}$.X foci. The total number of positive cells thereby significantly increased compared to either monotreatment (vs. MK1775: $p<$ 0.0125; vs. ${ }^{177}$ Lu-DOTA-chCE7: $\mathrm{p}<0.0125$; Fig. 4e).

The number of cells showing $\leq 5$ foci was similar for cells treated with ${ }^{177} \mathrm{Lu}$-labelled $\mathrm{mAb}$ or combination and amount of cells showing $\geq 6$ foci was comparable all in groups (Additional file 1: Table S2). Interestingly, upon combination of both agents the number of intensively positive cells raised from $2 \pm 1 \%\left({ }^{177} \mathrm{Lu}-\mathrm{DO}\right.$ TA-chCE7) and $5 \pm 3 \%$ (MK1775) to $15 \pm 7 \%$. Based on these numbers, the significant increase in overall positive cells for the combination is mostly due to the higher amounts of intensively positive cells.

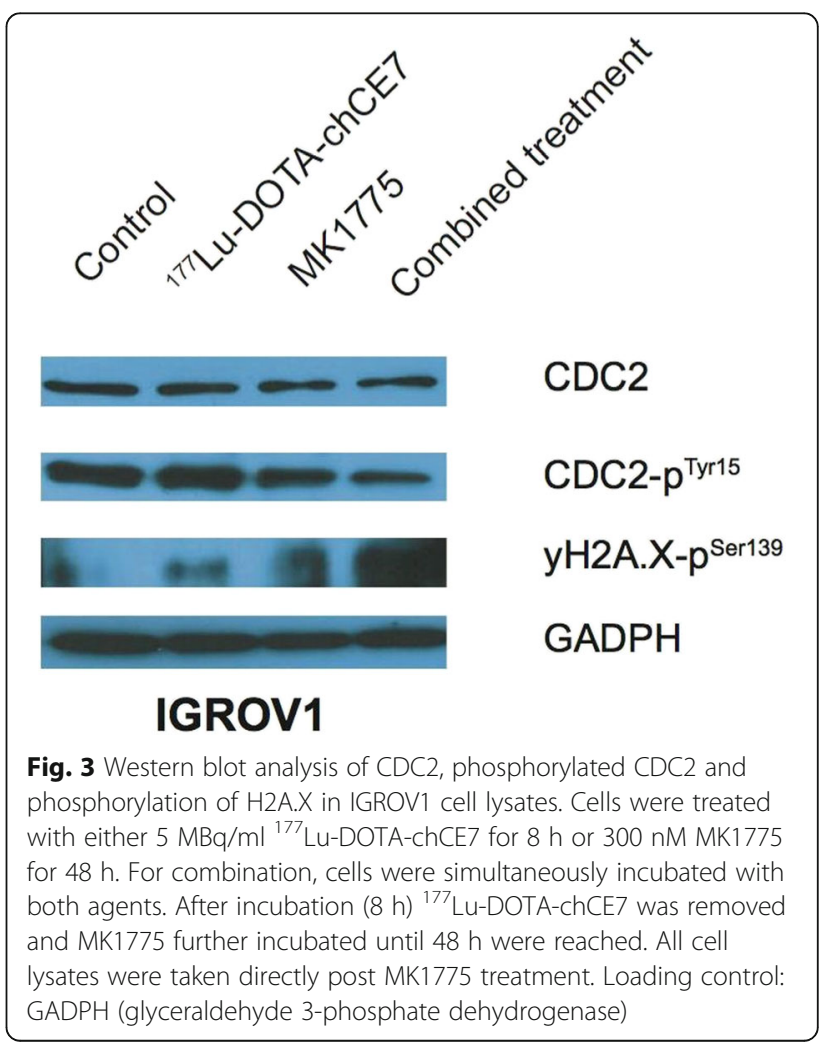



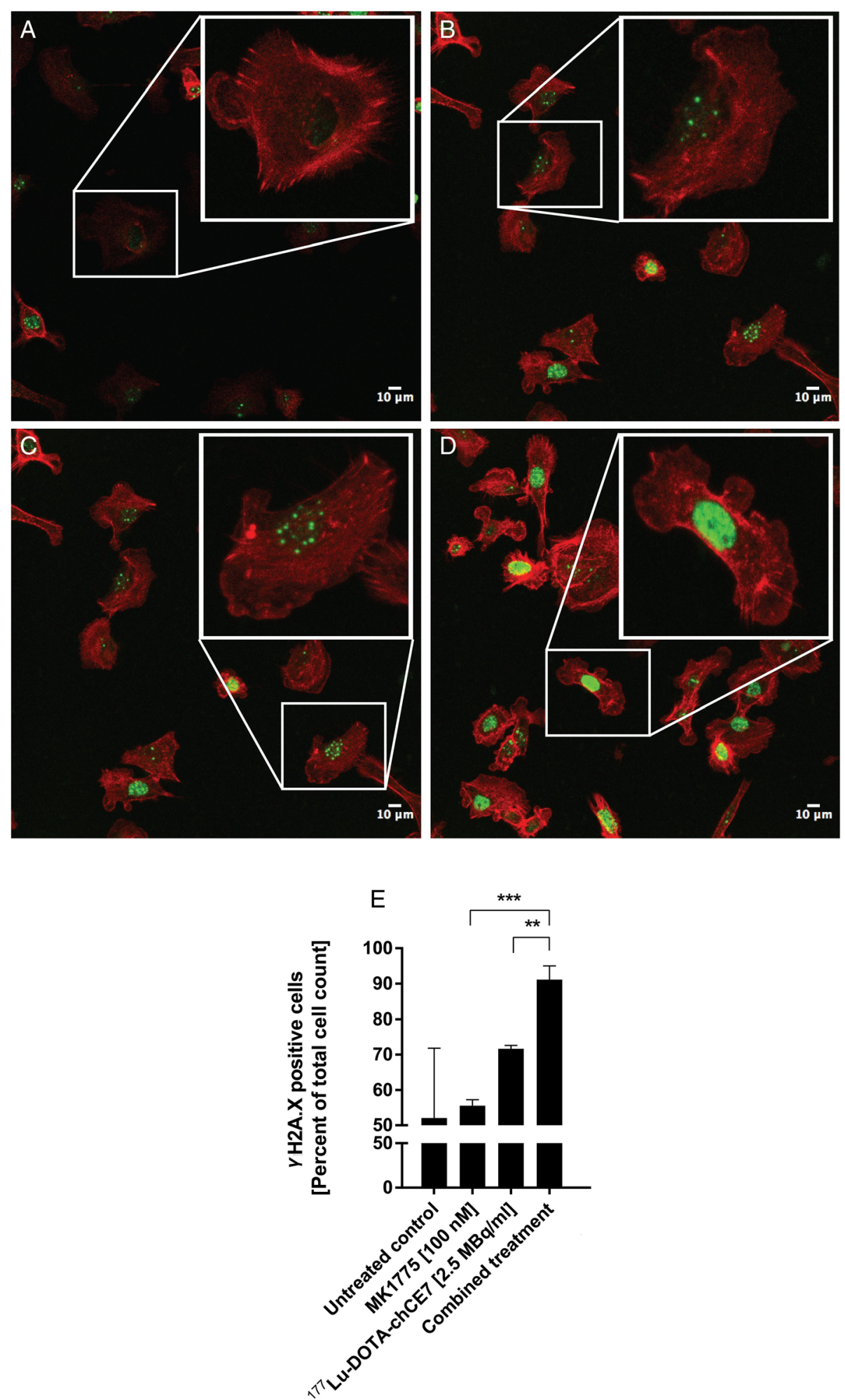

Fig. 4 Fluorescence microscopy of $\mathrm{YH} 2 \mathrm{~A}$.X. IGROV1 cells were incubated with $2.5 \mathrm{MBq}{ }^{177}$ Lu-DOTA-chCE7 for $4 \mathrm{~h}$ or with $100 \mathrm{nM}$ MK1775 for $48 \mathrm{~h}$. For combination, cells were simultaneously incubated with both agents. After $4 \mathrm{~h}$ incubation, ${ }^{177}$ Lu-DOTA-chCE7 was removed and MK1775 was further incubated until $48 \mathrm{~h}$ were reached. Cells were fixed and stained and $\mathrm{HH} 2 \mathrm{~A} . \mathrm{X}$ foci were counted and cells grouped depending on (a) no observed (b) $\leq 5$ (c) $\geq 6$ or (d) non-distinguishable $\gamma H 2 A$.X foci (intensively positive). a-d shows examples of IGROV1 cells with accordant numbers of $\mathrm{YH} 2 \mathrm{~A} . \mathrm{X}$ foci. (e) summarizes all $\mathrm{\gamma H} 2 \mathrm{~A} . \mathrm{X}$ positive cells expressed in percent of total cell numbers counted 
The combination of MK1775 and RIC increase earlyapoptosis compared to monotreatments in IGROV1 To investigate if induced DNA-DSBs result in apoptosis/ necrosis, flow cytometry analysis was performed. Cells were either untreated (Additional file 1: Figure S3A), or incubated with MK1775 (Additional file 1: Figure S3B), ${ }^{177} \mathrm{Lu}$-DOTA-chCE7 (Additional file 1: Figure S3C), or both (Additional file 1: Figure S3D). AnnexinV-FITC/PI double staining was used to distinguish between earlyand late-apoptosis/necrosis.

IGROV1 cells treated with ${ }^{177} \mathrm{Lu}$-DOTA-chCE7 demonstrated a doubling in early apoptotic cells compared to controls ( ${ }^{177} \mathrm{Lu}$-DOTA-chCE7: $8 \pm 2 \%$; control: $4 \pm$ $1 \%)$. The incubation with $300 \mathrm{nM}\left(\mathrm{IC}_{50}\right)$ MK1775 showed elevated levels of $29 \pm 10 \%$ of cells being early apoptotic. Combination resulted in a significant higher number of early-apoptotic IGROV1 cells compared to ${ }^{177} \mathrm{Lu}$-DOTA-chCE7 alone $(40 \pm 4 \% ; p<0.0125)$ indicating that enhanced levels of induced DSBs (Fig. 3 and 4e) resulted in significantly increased early-apoptosis immediately after combined treatment, but not significantly compared to MK1775 monotreatment $(p>0.0125)$. The amount of late-apoptotic or necrotic cells did not vary significantly (Table 2).

Immunohistology reveals significant higher levels of DNADSBs in SKOV3ip xenografts administered with MK1775 as a single agent or in combination with ${ }^{177}$ Lu-DOTAchCE7

Two in vivo experiments were performed in order to assess whether the promising results from the in vitro work could be confirmed. First we analysed the immunohistochemical expression of the $\gamma \mathrm{H} 2 \mathrm{~A}$.X antigen in SKOV3ip xenografts after administration of MK1775 and ${ }^{177} \mathrm{Lu}$-DOTA-chCE7. A generalized increase in $\gamma \mathrm{H} 2 \mathrm{~A} . \mathrm{X}$ expression (brown staining) was evident in the xenografts exposed to MK1775 (used alone or in combination; Fig. $5 \mathrm{c}$ and d), when compared to those untreated (Fig. 5a) or exposed to ${ }^{177} \mathrm{Lu}-\mathrm{DOTA}-\mathrm{chCE7}$ monotreatment (Fig. 5b). A 10-fold higher magnification clearly demonstrates the difference in $\gamma \mathrm{H} 2 \mathrm{~A}$.X expression levels in controls (Fig. 5e) and combination therapy treated tumours (Fig. 5f). Observations were confirmed by $\gamma \mathrm{H} 2 \mathrm{~A}$.X foci counts (Fig. 5g), which were conducted following the criteria applied to in vitro immunofluorescence experiments. Control tumours and those received ${ }^{177} \mathrm{Lu}$-DOTA-chCE7 showed identical levels of $\gamma \mathrm{H} 2 \mathrm{~A}$.X foci $\left({ }^{177} \mathrm{Lu}\right.$-DOTA-chCE7: $20 \pm 7 \%$; control: $\left.21 \pm 9 \%\right)$. In contrast, tumours treated with MK1775 or the combination therapy demonstrated similar, but higher amounts of $\gamma$ H2A.X foci (MK1775: $41 \pm 2 \%$; $p<0.0125$; combination: $42 \pm 8 \%, p>0.0125)$ compared to the RIT or control.

\section{RIT with ${ }^{177}$ Lu-DOTA-chCE7 and MK1775 reduces tumour growth in an IGROV-1 xenograft model}

In a second in vivo study we analysed the tumour growth inhibition effect of a ${ }^{177} \mathrm{Lu}$-DOTA-chCE7 RIT in combination with MK1775. We have previously shown that the use of lutetium-177 labelled anti-L1CAM antibody chCE7 for RIT of ovarian cancer is suitable [17] and a combination with paclitaxel improved the outcome [19]. For this study we used an advanced tumour stage (mean tumour volume: $362 \pm 150 \mathrm{~mm}^{3}$, maximal tumour size $\leq 700 \mathrm{~mm}^{3}$ ) to see whether RIT in combination with MK 1775 is able to curb a late stage of the disease. We observed a fast increase in tumour mass in the control mice and in the mice treated with MK1775 illustrated an unrestrained tumour growth (Fig. 6). In contrast, anti-L1CAM RIT alone or in combination with MK1775 markedly reduced tumour growth in comparison to the control group (PBS) and the MK1775 treated mice. The unspecific ${ }^{177} \mathrm{Lu}$-labelled control $\mathrm{mAb}$ in combination with MK1775 influenced the tumour growth to a moderate extent (Fig. 6). During therapy no signs of distress or lost of body weight of the mice were observed. Statistical calculations were omitted because of the modest sample size.

\section{Discussion}

Initially, we investigated five clinically relevant PKIs (MK1775, alisertib, MK2206, temsirolimus and saracatinib; clinical phase I-II) towards their cytotoxicity against the two OC cell lines IGROV1 (p53wt) and SKOV3ip (p53del). PKIs MK1775 and alisertib demonstrated the highest toxicity against both cell lines and were further examined towards their ability to increase the efficacy of ${ }^{177} \mathrm{Lu}$-labelled mAb chCE7. Both PKIs led to a decreased $\mathrm{IC}_{60}$-value of the RIC demonstrating their ability to sensitize the p53wt cell line IGROV1 towards the ${ }^{177} \mathrm{Lu}$-labelled mAb. However, MK1775 was more efficient in combination with ${ }^{177} \mathrm{Lu}$-DOTA-chCE7 compared to the PKI alisertib. We therefore continued to investigate the influence of different treatment sequences of

Table 2 Percentage of early- and late-apoptotic/necrotic IGROV1 cells after treatment with MK1775 and ${ }^{177}$ Lu-DOTA-chCE7

\begin{tabular}{|c|c|c|c|c|}
\hline IGROV1 & Untreated control & MK1775 [300 nM] & 177Lu-DOTA-chCE7 [5.0 MBq/ml] & Combined treatment \\
\hline Early-apoptosis & $4 \% \pm 1$ & $8 \% \pm 2$ & $29 \% \pm 10$ & $40 \% \pm 4$ \\
\hline Late-apoptosis/necrosis & $9 \% \pm 2$ & $10 \% \pm 2$ & $13 \% \pm 2$ & $12 \% \pm 1$ \\
\hline
\end{tabular}

The data were generated from three independent flow cytometry experiments 

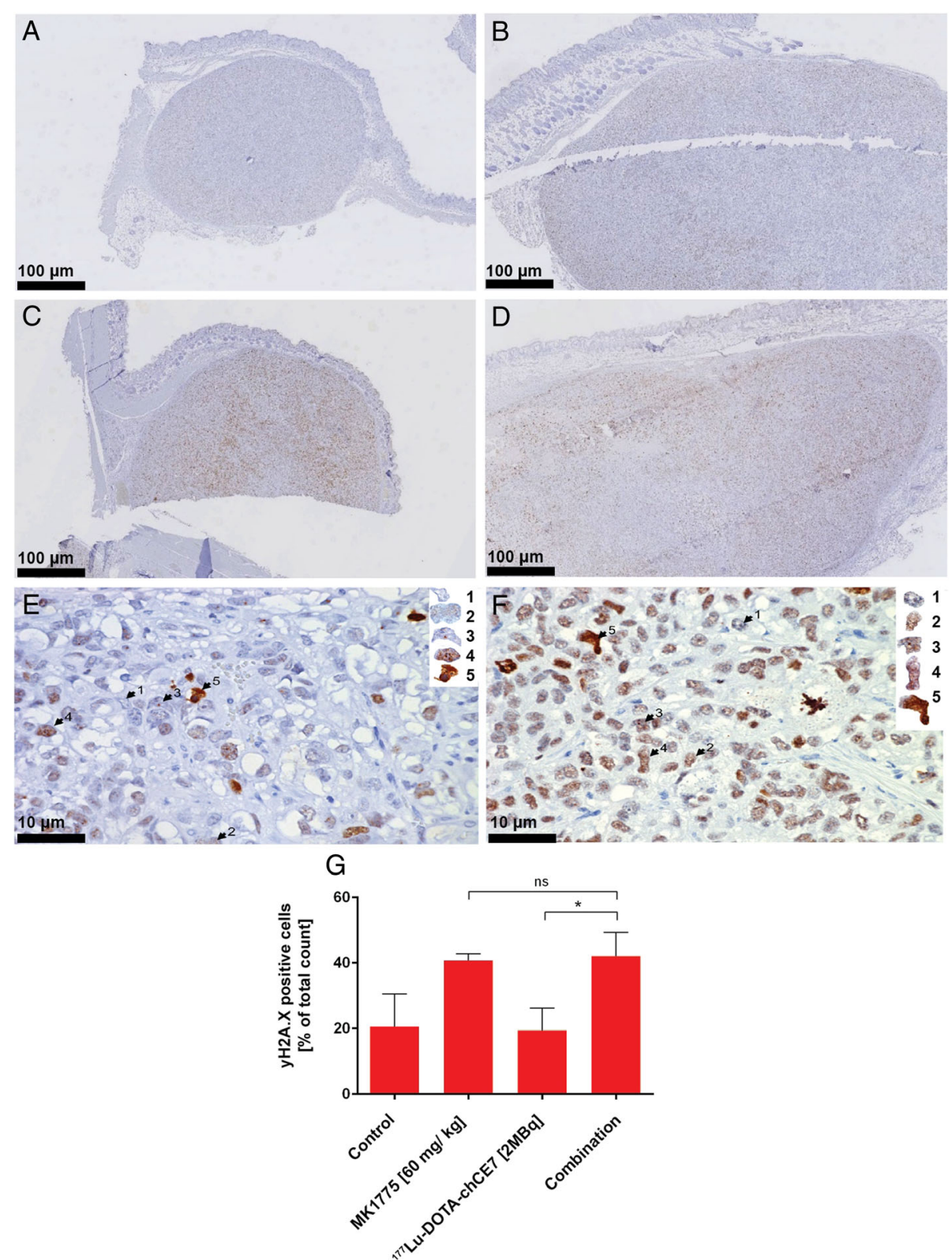

Fig. 5 yH2A.X expression in SKOV3ip xenografts. Mice either received (a) PBS (b) 2 MBq ${ }^{177}$ Lu-DOTA-chCE7, (c) 50 mg/kg MK1775 p.o. for 3 consecutive days, or (d) combined treatment of ${ }^{177}$ Lu-DOTA-chCE7 with 50 mg/kg MK1775 p.o. for 3 consecutive days started 48 h post RIT. 10fold higher magnifications are shown for (e) control tumours and (f) combination therapy tumour samples. $\gamma H 2 A$.X foci were counted and cells grouped depending on 1) no observed, 2) diffuse, 3) $\leq 5,4) \geq 6$, or 5) non-distinguishable $\gamma H 2 A . X$ foci (intensively positive). (g) summarizes counts of $y$ H2A.X expressing cells in percent of total cell count

combined MK1775 and ${ }^{177}$ Lu-DOTA-chCE7 applications on IGROV1 cells. The influence of the p53 status for sensitization to radiation by MK1775 is contradictory in the literature and is discussed in detail by Geenen and Schellens [40].

MK1775-based sensitization of tumour cells towards DNA-damaging agents and EBRT, by abrogating the G2 cell cycle checkpoint and inhibiting DNA-repair, has been previously demonstrated in various cancer cell lines
$[26,27,41-43]$. In our studies, the simultaneous application of ${ }^{177}$ Lu-DOTA-chCE7 and PKI MK1775, as well as a RIC pre-treatment resulted in 2-3-fold lower $\mathrm{IC}_{50}$-values compared to ${ }^{177} \mathrm{Lu}$-DOTA-chCE7 alone against IGROV1 cells. These results demonstrate the ability of MK1775 to sensitize IGROV1 cells towards RICs. Thus, our observations are in line with previous findings for combinations with EBRT [27, 43]. However, the addition of MK1775 prior the RIC showed no increased efficacy 


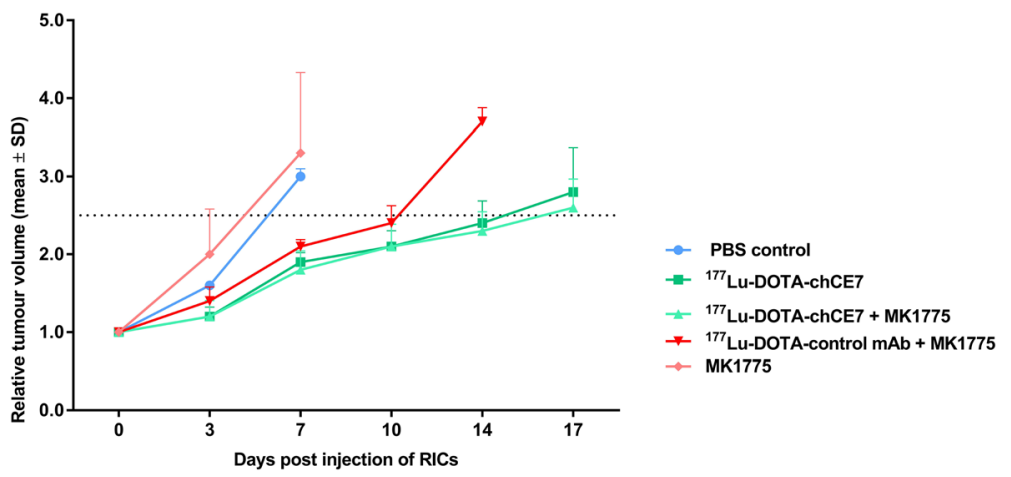

Fig. 6 Therapeutic efficacy of anti-L1CAM lutetium-177 RIT in combination with MK1775 in nude mice bearing subcutaneous IGROV1 tumours. Tumour-bearing nude mice $(n=4-6)$ were treated with $6 \mathrm{MBq}(50 \% \mathrm{MTA}){ }^{177}$ Lu-DOTA-chCE7, $6 \mathrm{MBq}{ }^{177}$ Lu-DOTA isotype control mAb, combination of both radiolabelled antibodies with MK1775 (given on three consecutive days, starting $48 \mathrm{~h}$ after RIT), only MK1775 and only PBS. Tumour growth curves were stopped when the first tumour in a treatment group reached $1500 \mathrm{~mm}^{3}$. The dashed line represents a 2.5 increase in mean relative tumour volumes $( \pm \mathrm{SD})$

compared to ${ }^{177} \mathrm{Lu}$-DOTA-chCE7, pointing out the importance of treatment sequence investigations. Previously it has been shown that upon radiation-induced DNA damages the phosphorylation of $\mathrm{CDC} 2$ is maintained for $12 \mathrm{~h}$ in order to arrest the cell cycle in the G/ $2 \mathrm{M}$ phase for DNA-repair [44]. We observed an increased radiosensitivity of IGROV1 cells when MK1775 was applied post or simultaneously with ${ }^{177} \mathrm{Lu}-\mathrm{DO}-$ TA-chCE7, suggesting that both, the abolishment of already existing $\mathrm{G} 2 / \mathrm{M}$ arrest and the inability to activate and maintain the G2/M arrest are forcing cells with damaged DNA into cell death.

We examined the induction of DNA-DSBs and apoptosis by mono- and combined treatments. Levels of histone H2A.X phosphorylation at Ser-139 (yH2A.X) was measured since it well correlates with the amount of existing DNA-DSBs [45]. Western blot analysis revealed slightly increased amounts of yH2A.X in ${ }^{177} \mathrm{Lu}-\mathrm{DO}-$ TA-chCE7 treated IGROV1 cells compared to controls $40 \mathrm{~h}$ post RIC application. For EBRT it has been shown that radiation-induced DNA-damages could be repaired within 12-24 h post treatment [44]. However, since mAb chCE7 internalizes and deposits the therapeutic radionuclide ${ }^{177} \mathrm{Lu}$ within the tumour cell, radiation exposure continues leading to increased amounts of present DBSs even after $40 \mathrm{~h}$ post ${ }^{177} \mathrm{Lu}$-DOTA-chCE7 removal.

Wee1-inhibiting MK1775 was shown to have multiple effects on tumour cells: First, replicative stress based on inactivated $\mathrm{CDC} 2$, enhanced initiation of DNA-replication and thus, shortage of nucleotides and lowered replication fork speed was observed [46]. Second, it was demonstrated that Wee1 also negatively regulates the Mus81-Eme1 endonuclease complex [47]. In turn, Wee1 inhibition most likely leads to increased Mus81-Eme1 endonuclease activity resulting in higher amounts of DNA-DSBs during DNA-replication. In line with these studies we showed enhanced levels of yH2A.X in IGROV1 cells after MK1775 applications compared to controls or ${ }^{177} \mathrm{Lu}$-DOTA-chCE7. Furthermore, the combined administration of MK1775 and ${ }^{177} \mathrm{Lu}-\mathrm{DOTA}-\mathrm{chCE7}$ showed higher levels of $\mathrm{yH} 2 \mathrm{~A} . \mathrm{X}$ in IGROV1 cells compared to MK1775 or ${ }^{177} \mathrm{Lu}$-labelled mAb alone. This indicates that Wee1 inhibition prevented the repair of irradiation induced DNA-DSBs. Additional evaluation of induced yH2A.X foci via immunofluorescence confirmed previously obtained results showing significantly increased amounts of $\mathrm{yH} 2 \mathrm{~A}$.X positive cells after combined application of MK1775 and ${ }^{177}$ Lu-DOTA-chCE7. The synergistic effect of MK1775 in combination with ${ }^{177} \mathrm{Lu}-\mathrm{DO}$ TA-chCE7 is therefore likely attributed to replicative stress and increased DNA damage induced by Wee1 inhibition.

Subsequent analysis of apoptosis/necrosis was performed to further examine if induced DNA-DSBs results in increased cell death. It has been shown in an osteosarcoma model that caspase activation upon combination of MK1775 and EBRT was significantly higher compared to only irradiated cells [43]. In our investigations, annexinV/PI analysis of IGROV1 cells revealed a significantly increased number of early-apoptotic cells for the combination of MK1775 with ${ }^{177}$ Lu-DOTA-chCE7 compared to ${ }^{177} \mathrm{Lu}$-DOTA-chCE7 treatment alone. This observation matches the previous findings from PosthumaDeBoer et al. [43]. Furthermore, our results demonstrate a correlation between the number of induced $\mathrm{yH} 2 \mathrm{~A}$.X foci and increased early-apoptosis.

SKOV3ip showed a 3-fold higher $\mathrm{IC}_{50}$-value compared to IGROV1 cells for ${ }^{177} \mathrm{Lu}$-DOTA-chCE7. This observation supports the results of previous experiments with EBRT showing the highest radioresistance for SKOV3 cells compared to other OC cell lines [48]. Reasons for radioresistance have been recently discussed by Cojoc et al. [49]. Cancer cells exhibit multiple mechanisms to 
avoid DNA-damage upon radiation including (i) the regulation of the cell cycles status, (ii) an improved DNA-repair machinery and (iii) enhanced DNA protection against reactive oxygen species (ROS) [49]. The occurrence of these mechanisms certainly varies between cell lines and is most likely more distinct in SKOV3ip than in IGROV1 cells.

Immunohistology of SKOV3ip xenograft samples confirmed in vitro results showing high sensitivity against MK1775 and high radioresistance. The treatment with MK1775 for 4 days was enough, to induce elevated levels of $y \mathrm{H} 2 \mathrm{~A}$.X in comparison to control and the treatment group with $2 \mathrm{MBq}{ }^{177} \mathrm{Lu}$-DOTA-chCE7. The combination therapy did not further increase the numbers of positive cells for yH2A.X. This suggests that MK1775 executes its toxicity in vivo, but additional application of $2 \mathrm{MBq}{ }^{177} \mathrm{Lu}$-DOTA-chCE7 did not produce further DNA-DSBs.

Increased therapeutic efficacy of EBRT in combination with MK1775 has been previously shown by Sarca et al. [50] in a glioblastoma model. Here we demonstrated that a combination of lutetium-177 RIT in combination with MK1775 in a late stage ovarian cancer model (IGROV1 xenograft) inhibited the tumour growth to a greater extent than the controls. The difference between RIT alone and the combination therapy was small and probably due to the modest group size. The influence of the lutetium-177 labelled unspecific antibody in combination with MK1775 on the tumour growth was moderate which is most likely due to a nonspecific accumulation of the $\mathrm{mAb}$ at the tumour site. Inflammations are sites where unspecific accumulation of radiolabelled antibodies occur [51]. The mice carried relative big tumours at therapy start and inflammation is often associated with tumour progression [52].

\section{Conclusion}

To our knowledge this is the first time that RIT was combined with MK1775 and the results were reported. MK1775 radiosensitizes ovarian cancer cells and a combination with ${ }^{177} \mathrm{Lu}$-labelled anti-tumour antibody increased the efficacy of the treatments. Our results strongly support a further development of a combination of MK1775 with RIT.

\section{Additional file}

Additional file 1: Figure S1. Flow cytometry analysis revealed that over 98\% of IGROV1 and SKOV3ip cells expressed L1CAM on the cell surface. Figure S2. MK1775 showed most promising radiosensitizing effect in IGROV1 human OC cells. Table S1. Combination index (CI). Detailed information on the Cl was shown. Data from Fig. 2 were used for the calculations. Table S2. Quantification of $\mathrm{YH} 2 \mathrm{~A} . \mathrm{X}$ foci in IGROV1 cells treated with either $100 \mathrm{nM} \mathrm{MK1775}$ (48 h), $2.5 \mathrm{MBq}{ }^{177}$ Lu-DOTA-chCE7 $(4 \mathrm{~h})$, or both. Detailed information about the $\mathrm{\gamma H} 2 \mathrm{~A} . \mathrm{X}$ foci $(\leq 5 /$ cell, $\geq 6$ / cell, Intensively positive cells) after treatments is shown in percent of total cell count. Figure S3. Apoptosis/necrosis analysis of IGROV1. AnnexinV-FITC/PI double staining was used to distinguish between early- and late-apoptosis/necrosis. Enhanced levels of induced DSBs resulted in significantly increased early-apoptosis immediately after combined treatment. (DOCX $410 \mathrm{~kb}$ )

\section{Acknowledgements}

We would like to thank Christine DePasquale for her help during the in vivo animal studies.

\section{Funding}

This work was supported by the Stiftung Krebsforschung Schweiz (Project No. KFS-2546-02-2010 and KFS-3585-02-2015 to Jürgen Grünberg) and the Mahari-Stiftung, Switzerland. The funding body had no influence in the design of the study and collection, analysis, and interpretation of data and in writing the manuscript.

\section{Availability of data and materials}

The datasets generated and/or analysed during the current study are available on request.

\section{Authors' contributions}

DL, NT, GP, SC, DV, PRS and JG designed and performed the experiments. $D L, T N, G P, D V, P R S$ and JG analysed the data. MB and RS helped with the interpretation of the data and writing of the manuscript. DL, NT and JG wrote the paper. All authors read and approved the final manuscript.

\section{Ethics approval and consent to participate}

All animal experiments were approved by the cantonal committee on animal experiments and permitted by the responsible cantonal authorities (permission number 75666, Kanton Aargau). The studies were conducted in compliance with the Swiss laws on animal protection.

\section{Consent for publication}

Not applicable.

\section{Competing interests}

The authors declare that they have no competing interests.

\section{Publisher's Note}

Springer Nature remains neutral with regard to jurisdictional claims in published maps and institutional affiliations.

\section{Author details}

${ }^{1}$ Center for Radiopharmaceutical Sciences ETH-PSI-USZ, Paul Scherrer Institute, 5232 Villigen PSI, Switzerland. ${ }^{2}$ Institut for Veterinary Pathology, University of Zurich, Zurich, Switzerland. ${ }^{3}$ Department of Chemistry and Applied Biosciences, ETH Zürich, Zurich, Switzerland.

Received: 7 February 2018 Accepted: 19 September 2018 Published online: 25 September 2018

\section{References}

1. Jelovac D, Armstrong DK. Recent Progress in the diagnosis and treatment of ovarian Cancer. Cancer J Clin. 2011;61(3):183-203.

2. McGuire WP. Cyclophosphamide and cisplatin compared with paclitaxel and cisplatin in patients with stage III and stage IV ovarian cancer (vol 334, pg 1, 1996). New Engl J Med. 1996, 334(16):1070-0.

3. Guarneri V, Piacentini F, Barbieri E, Conte PF. Achievements and unmet needs in the management of advanced ovarian cancer. Gynecol Oncol. 2010;117(2):152-8

4. Ferrandina G, Ludovisi M, Lorusso D, Pignata S, Breda E, Savarese A, Medico PD, Scaltriti L, Katsaros D, Priolo D, et al. Phase III trial of gemcitabine compared with Pegylated liposomal doxorubicin in progressive or recurrent ovarian Cancer. J Clin Oncol. 2008;26(6):890-6.

5. Huinink WT, Lane SR, Ross GA, Grp ITS. Long-term survival in a phase III, randomised study of topotecan versus paclitaxel in advanced epithelial ovarian carcinoma. Ann Oncol. 2004;15(1):100-3. 
6. Rose PG, Blessing JA, Mayer AR, Homesley HD. Prolonged oral etoposide as second-line therapy for platinum-resistant and platinumsensitive ovarian carcinoma: a gynecologic oncology group study. J Clin Oncol. 1998;16(2):405-10.

7. Itamochi H, Oishi T, Shimada M, Sato S, Uegaki K, Naniwa J, Sato S, Nonaka M, Terakawa N, Kigawa J, et al. Inhibiting the mTOR pathway synergistically enhances cytotoxicity in ovarian Cancer cells induced by etoposide through upregulation of c-Jun. Clin Cancer Res. 2011;17(14):4742-50.

8. Banerjee S, Kaye SB. New strategies in the treatment of ovarian Cancer: current clinical perspectives and future potential. Clin Cancer Res. 2013; 19(5):961-8.

9. Frederick PJ, Straughn JM, Alvarez RD, Buchsbaum DJ. Preclinical studies and clinical utilization of monoclonal antibodies in epithelial ovarian cancer. Gynecol Oncol. 2009;113(3):384-90.

10. Berek J, Taylor P, McGuire W, Smith LM, Schultes B, Nicodemus CF. Oregovomab maintenance Monoimmunotherapy does not improve outcomes in advanced ovarian Cancer. J Clin Oncol. 2009;27(3):418-25.

11. Schilder RJ, Pathak HB, Lokshin AE, Holloway RW, Alvarez RD, Aghajanian C, Min H, Devarajan K, Ross E, Drescher CW, et al. Phase II trial of single agent cetuximab in patients with persistent or recurrent epithelial ovarian or primary peritoneal carcinoma with the potential for dose escalation to rash. Gynecol Oncol. 2009;113(1):21-7.

12. Bookman MA, Darcy KM, Clarke-Pearson D, Boothby RA, Horowitz IR. Evaluation of monoclonal humanized anti-HER2 antibody, Trastuzumab, in patients with recurrent or refractory ovarian or primary peritoneal carcinoma with overexpression of HER2: a phase II trial of the gynecologic oncology group. J Clin Oncol. 2003;21(2):283-90.

13. Leone Roberti Maggiore U, Bellati F, Ruscito I, Gasparri ML, Alessandri F, Venturini PL, Ferrero S. Monoclonal antibodies therapies for ovarian cancer. Expert Opin Biol Ther. 2013;13(5):739-64.

14. Hong X, O'Donnell JP, Salazar CR, Van Brocklyn JR, Barnett KD, Pearl DK, deCarvalho AC, Ecsedy JA, Brown SL, Mikkelsen T, et al. The selective Aurora-a kinase inhibitor MLN8237 (alisertib) potently inhibits proliferation of glioblastoma neurosphere tumor stem-like cells and potentiates the effects of temozolomide and ionizing radiation. Cancer Chemother Pharmacol. 2014;73(5):983-90.

15. Carrassa L, Chilà R, Lupi M, Ricci F, Celenza C, Mazzoletti M, Broggini M, Damia G. Combined inhibition of Chk1 and Wee1: in vitro synergistic effect translates to tumor growth inhibition in vivo. Cell Cycle. 2012;11(13):2507-17.

16. Purnell PR, Mack PC, Tepper CG, Evans CP, Green TP, Gumerlock PH, Lara PN, Gandara DR, Kung H-J, Gautschi O. The Src inhibitor AZD0530 blocks invasion and may act as a Radiosensitizer in lung Cancer cells. J Thorac Oncol. 2009;4(4):448-54.

17. Fischer E, Grünberg J, Cohrs S, Hohn A, Waldner-Knogler K, Jeger S, Zimmermann K, Novak-Hofer I, Schibli R. L1-CAM-targeted antibody therapy and $177 \mathrm{Lu}$-radioimmunotherapy of disseminated ovarian cancer. Int J Cancer. 2012;130(11):2715-21.

18. Knogler K, Grünberg J, Zimmermann K, Cohrs S, Honer M, Ametamey S, Altevogt P, Fogel M, Schubiger PA, Novak-Hofer I. Copper-67 Radioimmunotherapy and growth inhibition by anti-L1-cell adhesion molecule monoclonal antibodies in a therapy model of ovarian Cancer metastasis. Clin Cancer Res. 2007;13(2):603-11.

19. Lindenblatt D, Fischer E, Cohrs S, Schibli R, Grünberg J. Paclitaxel improved anti-L1CAM lutetium-177 radioimmunotherapy in an ovarian cancer xenograft model. EJNMMI Res. 2014;4(1):54.

20. Grünberg J, Lindenblatt D, Dorrer H, Cohrs S, Zhernosekov K, Koster U, Turler A, Fischer E, Schibli R. Anti-L1CAM radioimmunotherapy is more effective with the radiolanthanide terbium-161 compared to lutetium-177 in an ovarian cancer model. Eur J Nucl Med Mol Imaging. 2014;41(10):1907-15.

21. Fogel M, Gutwein P, Mechtersheimer S, Riedle S, Stoeck A, Smirnov A, Edler L, Ben-Arie A, Huszar M, Altevogt P. L1 expression as a predictor of progression and survival in patients with uterine and ovarian carcinomas. Lancet. 2003;362(9387):869-75.

22. Kiefel H, Bondong S, Hazin J, Ridinger J, Schirmer U, Riedle S, Altevogt P. L1CAM: a major driver for tumor cell invasion and motility. Cell Adhes Migr. 2012;6(4):374-84.

23. Matulonis UA, Sharma S, Ghamande S, Gordon MS, Del Prete SA, RayCoquard I, Kutarska E, Liu H, Fingert H, Zhou X, et al. Phase II study of MLN8237 (alisertib), an investigational Aurora a kinase inhibitor, in patients with platinum-resistant or -refractory epithelial ovarian, fallopian tube, or primary peritoneal carcinoma. Gynecol Oncol. 2012;127(1):63-9.
24. Parker $\mathrm{L}$, Piwnica-Worms $\mathrm{H}$. Inactivation of the $\mathrm{p} 34 \mathrm{cdc}$-cyclin $\mathrm{B}$ complex by the human WEE1 tyrosine kinase. Science. 1992;257(5078):1955-7.

25. Watanabe N, Broome M, Hunter T. Regulation of the human WEE1Hu CDK tyrosine 15-kinase during the cell cycle. EMBO J. 1995;14(9):1878-91.

26. De Witt Hamer PC, Mir SE, Noske D, Van Noorden CJ, Wurdinger T. WEE1 kinase targeting combined with DNA-damaging cancer therapy catalyzes mitotic catastrophe. Clin Cancer Res. 2011;17(13):4200-7.

27. Caretti $V$, Hiddingh L, Lagerweij T, Schellen P, Koken PW, Hulleman E, van Vuurden DG, Vandertop WP, Kaspers GJ, Noske DP, et al. WEE1 kinase inhibition enhances the radiation response of diffuse intrinsic pontine gliomas. Mol Cancer Ther. 2013;12(2):141-50.

28. Behbakht K, Sill MW, Darcy KM, Rubin SC, Mannel RS, Waggoner S, Schilder RJ, Cai KQ, Godwin AK, Alpaugh RK. Phase II trial of the mTOR inhibitor, temsirolimus and evaluation of circulating tumor cells and tumor biomarkers in persistent and recurrent epithelial ovarian and primary peritoneal malignancies: a gynecologic oncology group study. Gynecol Oncol. 2011;123(1):19-26.

29. Emons G, Kurzeder C, Schmalfeldt B, Neuser P, de Gregorio N, Pfisterer J, Park-Simon TW, Mahner S, Schroder W, Luck HJ, et al. Temsirolimus in women with platinum-refractory/resistant ovarian cancer or advanced/ recurrent endometrial carcinoma. A phase II study of the AGO-study group (AGO-GYN8). Gynecol Oncol. 2016;140(3):450-6.

30. Gil del Alcazar CR, Hardebeck MC, Mukherjee B, Tomimatsu N, Gao X, Yan J, Xie XJ, Bachoo R, Li L, Habib AA, et al. Inhibition of DNA double-strand break repair by the dual PI3K/mTOR inhibitor NVP-BEZ235 as a strategy for radiosensitization of glioblastoma. Clin Cancer Res. 2014;20(5):1235-48.

31. Hirai H, Sootome H, Nakatsuru Y, Miyama K, Taguchi S, Tsujioka K, Ueno Y, Hatch H, Majumder PK, Pan BS, et al. MK-2206, an allosteric Akt inhibitor, enhances antitumor efficacy by standard chemotherapeutic agents or molecular targeted drugs in vitro and in vivo. Mol Cancer Ther. 2010;9(7):1956-67.

32. Connolly E, Sun Y, Chao K, Hei T. Abstract PD09-09: the Akt inhibitor MK-2206 is an effective radio-sensitizer of p53 deficient triple negative breast cancer (TNBC) cells. Cancer Res. 2012;72(24 Supplement):PD09-09.

33. Yu D, Wolf JK, Scanlon M, Price JE, Hung MC. Enhanced C-erbB-2/neu expression in human ovarian cancer cells correlates with more severe malignancy that can be suppressed by E1A. Cancer Res. 1993;53(4): 891-8.

34. Grünberg J, Knogler K, Waibel R, Novak-Hofer I. High-yield production of recombinant antibody fragments in HEK-293 cells using sodium butyrate. BioTechniques. 2003;34(5):968-72

35. Lindmo T, Boven E, Cuttitta F, Fedorko J, Bunn PA,J. Determination of the immunoreactive fraction of radiolabeled monoclonal antibodies by linear extrapolation to binding at infinite antigen excess. J Immunol Methods. 1984;72(1):77-89.

36. Franken NA, Rodermond HM, Stap J, Haveman J, van Bree C. Clonogenic assay of cells in vitro. Nat Protoc. 2006;1(5):2315-9.

37. Moser R, Xu C, Kao M, Annis J, Lerma LA, Schaupp CM, Gurley KE, Jang IS, Biktasova A, Yarbrough WG, et al. Functional kinomics identifies candidate therapeutic targets in head and neck cancer. Clin Cancer Res. 2014;20(16): 4274-88.

38. Hoggatt AF, Hoggatt J, Honerlaw M, Pelus LM. A spoonful of sugar helps the medicine go down: a novel technique to improve oral gavage in mice. J Amer Assoc Lab Anim Sci. 2010;49(3):329-34.

39. Zhao L, Au JL, Wientjes MG. Comparison of methods for evaluating drugdrug interaction. Front Biosci. 2010;2:241-9.

40. Geenen JJJ, Schellens JHM. Molecular Pathways: Targeting the Protein Kinase Wee1 in Cancer. Clin Cancer Res. 2017;23(16):4540-544.

41. Karnak D, Engelke CG, Parsels LA, Kausar T, Wei D, Robertson JR, Marsh KB, Davis MA, Zhao L, Maybaum J, et al. Combined inhibition of Wee1 and PARP1/2 for radiosensitization in pancreatic cancer. Clin Cancer Res. 2014; 20(19):5085-96.

42. Hirai H, Arai T, Okada M, Nishibata T, Kobayashi M, Sakai N, Imagaki K, Ohtani J, Sakai T, Yoshizumi T, et al. MK-1775, a small molecule Wee1 inhibitor, enhances anti-tumor efficacy of various DNA-damaging agents, including 5-fluorouracil. Cancer Biol Ther. 2010;9(7):514-22.

43. PosthumaDeBoer J, Wurdinger T, Graat HC, van Beusechem WW, Helder MN, van Royen BJ, Kaspers GJ. WEE1 inhibition sensitizes osteosarcoma to radiotherapy. BMC Cancer. 2011;11:156. 
44. Kim MJ, Lee JY, Lee SJ. Transient suppression of nuclear Cdc2 activity in response to ionizing radiation. Oncol Rep. 2008;19(5):1323-9.

45. Sharma A, Singh K, Almasan A. Histone H2AX phosphorylation: a marker for DNA damage. Methods Mol Biol. 2012;920:613-26.

46. Beck H, Nahse-Kumpf V, Larsen MS, O'Hanlon KA, Patzke S, Holmberg C, Mejlvang J, Groth A, Nielsen O, Syljuasen RG, et al. Cyclin-dependent kinase suppression by WEE1 kinase protects the genome through control of replication initiation and nucleotide consumption. Mol Cell Biol. 2012;32(20): 4226-36.

47. Dominguez-Kelly R, Martin Y, Koundrioukoff $S$, Tanenbaum ME, Smits VA, Medema RH, Debatisse M, Freire R. Wee1 controls genomic stability during replication by regulating the Mus81-Eme1 endonuclease. J Cell Biol. 2011; 194(4):567-79.

48. Petru E, Sevin BU, Gottlieb Ch. Radiosensitivity Patterns of Four Human Ovarian Cancer Cell Linesin Vitro. Gynecol Oncol. 1997:64(3):490-92.

49. Cojoc M, Mäbert K, Muders MH, Dubrovska A. A role for cancer stem cells in therapy resistance: Cellular and molecular mechanisms. Semin Cancer Biol. 2015;31:16-27.

50. Sarcar B, Kahali S, Prabhu AH, Shumway SD, Xu Y, Demuth T, Chinnaiyan P. Targeting Radiation-Induced G2 Checkpoint Activation with the Wee-1 Inhibitor MK-1775 in Glioblastoma Cell Lines. Mol Cancer Ther. 2011;10(12): 2405-414.

51. Rubin RH, Young LS, Hansen WP, Nedelman M, Wilkinson R, Nelles MJ, Callahan R, Khaw BA, Strauss HW: Specific and nonspecific imaging of localized Fisher immunotype 1 Pseudomonas aeruginosa infection with radiolabeled monoclonal antibody. J Nucl Med. 1988;29(5):651-56.

52. Lisa M. Coussens, Zena Werb. Inflammation and cancer. Nature. 2002;420 (6917):860-67.

Ready to submit your research? Choose BMC and benefit from:

- fast, convenient online submission

- thorough peer review by experienced researchers in your field

- rapid publication on acceptance

- support for research data, including large and complex data types

- gold Open Access which fosters wider collaboration and increased citations

- maximum visibility for your research: over $100 \mathrm{M}$ website views per year

At $\mathrm{BMC}$, research is always in progress.

Learn more biomedcentral.com/submissions 